BOOK REVIEW

\section{Prude: Lessons I Learned When My Fiancé Filmed Porn}

Emily Southwood. Berkeley, CA: Seal Press, 2013. ISBN-13: 978-1-580-05498-0. Price: f9.85. Pages: 251 (paperback)

This is the plot. Emily, newly engaged to film-maker Robbie, ecstatically contemplates their future life together. Then he drops the bombshell. He's been asked to film a documentary about the porn industry, and when Emily doesn't immediately object, takes on the project. But how does she feel about that?

What follows is an exploration of the answer to that question. How does Emily feel about porn in general? How does she feel in particular about the scenes and activities her fiancé is filming? Like many of us, she is conflicted, wanting on the one hand to be relaxed about sexuality, on the other hand feeling that pornography is against her values.

The book examines - without, be warned, inhibition - varying aspects of the topic. We consider the philosophical issues of misogyny, coercion, infidelity, and the overlap between love and sex, as well as the practicalities of hand jobs, threesomes, anal sex and 'squirting' (all of these words serve as chapter headings). The author's conclusions are always thoughtful as well as thoughtprovoking, while the initial and final chapters especially left this reader both understanding more about the porn industry and questioning her own attitudes to it.

That said, the book also stumbles. For as its subtitle suggests, it is not only an examination of porn but also of the author's relationship with her fiancé. And while the interactions between them were fascinating in Chapter 1, by Chapter 11 they were tiresome. The repeated formula - new porn topic; rumination about porn topic; argument with fiancé; complaint to friends about argument with fiancé; fragile reconciliation - didn't always support the deeper issues.

The ending - where Emily finally asks Robbie to resign from the porn project, he agrees at once, and they then live happily ever after - was what happened in real life. Yet it still seems somehow simplistic. Successful lifetime commitment is surely easier when each partner is willing to do what the other wants, but it is not always an instant solution to marital disharmony. More crucially for the book, it is not a solution to the challenges of porn. Emily may have reached inner peace because Robbie stopped filming hot babes, but the rest of us are still struggling with huge social, cultural and ethical dilemmas.

Despite this caveat, Emily's writing style is delightful; she addresses the sometimes disturbing porn themes without condescension or condemnation, and this is a brave attempt at tackling difficult issues. If you are looking for an academic, politically correct or feminist treatment of the topic then pass. If you are looking to enjoy an entertaining, often eye-popping read with significant added insight, then buy.

Reviewed by Susan Quilliam

Writer, Broadcaster, Consultant and Trainer, Cambridge, UK; susan@susanquilliam.com

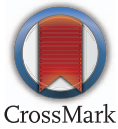

J Fam Plann Reprod Health Care 2015;41:53. doi:10.1136/jprhc-2014-101125 